\title{
Adult ADHD, Comorbidities and Impact on Functionality in a Population of Individuals with Personality Disorders - DSM IV and DSM 5 Perspectives
}

\author{
Laura Aelenei ${ }^{1,2}$, Dan Prelipceanu ${ }^{1}$
}

\begin{abstract}
Background: ADHD and personality disorders show a considerable symptom overlap. Sometimes these disorders are complicated by comorbidities, the most frequent being depression, alcohol and drug abuse or dependence. Their presence impact the functionality of patients. The introduction of DSM 5 brought a new perspective on the approach of these disorders. Material and methods: The study consists of the evaluation of a sample of 140 individuals with personality disorders. From this sample it has been determined the proportion of the ADHD patients by using a specific scale (DIVA). First the analysis has been made using the DSM IV criteria. Two groups were formed: A - the ADHD group and B - the personality disorder non ADHD group. The possible comorbidities in the two groups A and B have been determined using the instrument MINI. The impact on functionality was evaluated with the scale WFIRS and the overall severity with the presence of hospitalizations. The same analysis has been made using the DSM 5 criteria. Then a comparison between the two classifications has been made. Results: The prevalence of ADHD in the initial sample of the personality disorder patients has been $29.3 \%$ after the DSM IV classification and $44.3 \%$ after the DSM 5. Moreover, the prevalence of depression, alcohol, drug abuse and dependence and other comorbidities has been determined in the ADHD and non-ADHD group, first using the DSM IV criteria, then using the DSM 5 criteria. A comparison between the two situations has been made, as well as an evaluation of the impact on functionality. Conclusions: The presence of depression, substance use disorders other than alcohol and alcohol use disorders are not significant in the differentiation of ADHD patients from the population of personality disorder nonADHD patients. The overall severity and the impact on functionality as assessed with the presence of hospitalizations and the WFIRS scale show a significant importance in differentiating the intensity of ADHD symptomatology.
\end{abstract}

Keywords: adult ADHD, personality disorder, depression, alcohol, drugs, functionality

\section{Rezumat}

Context: ADHD și tulburările de personalitate pot avea o prezentare clinică care să cuprindă simptome comune. Uneori aceste tulburări pot fi complicate de comorbidități, cele mai frecvente fiind depresia, abuzul și dependența de alcool și alte droguri. Prezența acestora influențează funcționalitatea pacienților. Introducerea DSM 5 aduce o nouă perspectivă asupra abordării acestor patologii. Material și metode: Studiul constă în evaluarea unui lot de 140 de indivizi cu tulburări de personalitate. Din acest lot s-a determinat proporția pacienților ADHD folosind o scală specifică de diagnostic (DIVA). Întâi s-a realizat analiza conform criteriilor DSM IV. S-au format două grupuri: A grupul ADHD și B - grupul de tulburări de personalitate non ADHD. Alte posibile comorbidități în cele două grupuri au fost determinate folosind MINI. Impactul asupra functionalității a fost evaluat cu scala WFIRS și severitatea

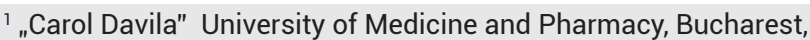
Romania

2 „Sfantul Stelian" Hospital, Bucharest, Romania

\section{Corresponding author.}

Laura Aelenei, „Carol Davila" University of Medicine and

Pharmacy, Bucharest, Romania.

E-mail: laura.aelenei.13@gmail.com 
globală cu prezența spitalizărilor. Aceeași analiză a fost efectuată folosind criteriile DSM 5. Apoi a fost realizată o comparație între cele două clasificări. Rezultate: Prevalența ADHD în lotul inițial de pacienți cu tulburări de personalitate a fost de 29,3\% după clasificarea DSM IV și 44,3\% după DSM 5. În continuare s-a determinat prevalența depresiei, a abuzului și dependenței de alcool și alte droguri și a altor comorbidități în grupurile ADHD și nonADHD, întâi după criteriile DSM IV, apoi DSM 5. O comparație între cele două situații a fost realizată, ca și impactul asupra funcționalității. Concluzii: Prezența depresiei, a tulburărilor prin uz de substanțe altele decât alcool și a tulburărilor legate de alcool nu este semnificativă în diferențierea pacienților ADHD față de pacienții cu tulburare de personalitate nonADHD. Severitatea globală și impactul asupra funcționalității evaluate prin prezența spitalizărilor și scala WFIRS arată o importanță semnificativă în diferențierea intensității simptomatologiei ADHD. Concluzii: Prezența depresiei, a tulburărilor prin uz de substanțe altele decât alcool și a tulburărilor legate de alcool nu este semnificativă în diferențierea pacienților ADHD față de pacienții cu tulburare de personalitate nonADHD. Severitatea globală și impactul asupra funcționalității evaluate prin prezența spitalizărilor și scala WFIRS arată o importanță semnificativă în diferențierea intensității simptomatologiei ADHD.

Cuvinte cheie: ADHD la adult, tulburare de personalitate, depresie, alcool, droguri, funcționalitate

\section{BACKGROUND}

The DSM 5 perspective made psychiatrists turn their attention towards some disorders like personality disorders or ADHD. Having in mind the different approaches regarding these pathologies we can say that there are some issues regarding the diagnostic process that can be discussed ${ }^{1}$.

According to the DSM IV, personality disorders are enduring, pervasive behavioral and thinking patterns that are inflexible and maladaptive. Described not as episodic mental or emotional states that correspond to Axis I disorders, personality disorders show stable characteristics that cause distress or impairment in multiple environments ${ }^{2,3}$.

In $\mathrm{ADHD}$ we find inattention, hyperactivity and impulsivity in all aspects and environments of everyday life. Time often produces a reduction of this symptomatology. There have been many correlations in literature regarding ADHD in the adult population and personality disorders, the relationship being explained in multiple ways. An aspect that can be discussed is the fact that in many cases this symptomatology that persists longitudinally with possible fluctuations can be complicated by the emergence of other comorbiditi$\mathrm{es}^{4,5}$.

Many studies have been conducted to evaluate the relationship between the personality disorders and ADHD. Miller et al. conducted a longitudinal study that assessed the possible relationship between ADHD in childhood, personality disorders in adult life and other comorbidities and concluded that the risk of developing a personality disorder is increased in the individuals with ADHD. The most frequent were borderline antisocial, avoidant and narcissistic personality disorders ${ }^{6}$.
Some ADHD individuals show an important behavioral dimension that includes risky behaviors. Some show antisocial activity and then possible detention. There has been an interest in studying individuals in detention. Torgersen et al. found a proportion of $44 \%$ ADHD in a population of antisocial personality disorder patients (2007) ${ }^{7}$. Another study by Roesler (2004) identified $45 \%$ ADHD in a population of antisocial personality disorder ${ }^{8}$.

The DSM 5 classiffication changed the pespective on the ADHD pathology. The number of the criteria necessary is smaller and the age of the onset of the symptomatology has changed. The diagnosis is therefore easier. The age of the onset has changed from 7 to 12 years old, the number of symptoms are 5 instead of 6 in the adults ${ }^{1}$.

This study tries to assess the presence of ADHD symptomatology in a sample of individuals diagnosed with a personality disorder. Moreover, the evaluation can identify several comorbidities that can modify the clinical presentation.

Mood disorders are frequent comorbidities of ADHD. Their presence can be episodic and symptomatology can be fluctuating across the life span. ADHD symptomatology can often associate an affective dimension. Sometimes we can find emotional liability, impulsivity, irascibility, anxiety. Other symptoms are reduced self-esteem, sadness, depressive ideas ${ }^{9,10}$.

Other possible diagnoses that can overlap with ADHD are substance use disorders and alcohol use disorders ${ }^{11-13}$. Alcohol abuse and dependence can often add some behavioral modification and determine risky behaviors like driving intoxicated, fighting, violent behavior or other antisocial actions.

Substance use disorders can also be discussed in relation to the ADHD treatment strategies. There has 
been a discussion about ADHD as a risk factor for substance use disorders (SUD). This correlates with the presence of impulsivity, risky behaviors, characteristics of ADHD patients ${ }^{14}$.

Substance abuse and dependence has been extensively studied in relation to ADHD pathology ${ }^{15-19}$. Some studies compared the alcohol and drug abuse and dependence pathologies and found that the drug abusers show greater ADHD pathology compared to the alcohol abusers ${ }^{15,16}$.

The ADHD medication is represented by the stimulant and non-stimulant substances. The stimulant medication are MTH (methylphenidate) or AMPHbased medications (amphetamine), substances that present an addictive risk. This is why many studies studied the risks and benefits of prescribing stimulants to ADHD patients ${ }^{20}$.

Other comorbidities present in ADHD patients can be anxiety, impulse-related behaviors like gambling, somatoform disorders.

\section{MATERIAL AND METHODS}

The study is designed as a cross-sectional, non-interventional one. The sample of patients studied consists of 140 individuals diagnosed with a personality disorder from cluster A, B or C. Some of them were hospitalized, some of them were outpatients.

The inclusion criteria used have been a previous diagnosis of a personality disorder, after the DSM IV criteria, the consent to being further investigated. The exclusion criteria have been the refuse to sign the informed consent, the impossibility of finishing the diagnostic scales and symptoms that represent an emergency at the time of the evaluation. From this sample it has been determined the proportion of the ADHD patients by using a specific scale for the ADHD pathology: DIVA (The Diagnostic Interview for ADHD in Adults) ${ }^{21}$. Two groups were formed: A - the ADHD group and $\mathrm{B}$ - the personality disorder non ADHD group. The possible comorbidities in the two groups $\mathrm{A}$ and $\mathrm{B}$ have been determined using the instrument MINI (Mini International Neuropsychiatric Interview). The impact of functionality has been determined using the scale WFIRS (Weiss Functional Impairment Rating Scale).

The diagnosis of ADHD in adults is made initially after the DSM IV classification, when more than 6 from 9 criteria from the inattentive or from the hyperactive/impulsive domain are met. Moreover, the diagnosis of ADHD in adults is revaluated using the
DSM 5 criteria, that is when 5 from 9 criteria are met. Then, a comparison between the two perspectives is made, having in mind the comorbidities and their impact on functionality.

The patients have been evaluated and the demographic and medical data has been collected. The standardized instruments used were the following rating scales: DIVA, WFIRS, ASRS, CGIs, GAF, MINI. The DIVA evaluation gives us a total score, that means the total number of positive items, the DIVA attention score or the DIVA hyperactive/impulsive score. From the evaluation with the WFIRS we use the total score and the risk score.

Some demographic data are: age, education, marital status, children. Other elements are the medical pathology, somatic or psychiatric, hospitalizations, treatments, employment, use of substances (coffee, smoking, alcohol).

The data has been collected and inserted into an Excel table. Data analysis provided information about the prevalence of $\mathrm{ADHD}$, and then the prevalence of other comorbidities (depression, alcohol and drug pathology) in the two groups (ADHD and personality disorder nonADHD group), as well as the impact on functionality.

Some limits of the study are: the retrospective assessment of a childhood diagnosis that can be problematic, the information from the patients that can be subjective, the difficult access to medical and the absence of the information from the family members. The transversal approach can also be a problem in assessing the comorbidities present retrospectively.

\section{RESULTS}

The initial sample of patients consisted of 140 individuals diagnosed with a personality disorder.

\section{A. The DSM IV perspective}

First, we referred to the ADHD diagnosis. The evaluation using the DIVA gave the following results: from the 140 of the individuals with a personality disorder, 41 could be diagnosed with adult ADHD.

The sample was divided into two groups: A- the ADHD group (individuals with a personality disorder and $\mathrm{ADHD}$ ), $\mathrm{B}$ - the personality disorder group (individuals with a personality disorder without ADHD).

A - the ADHD group - 41 patients (29.3\%)

$\mathrm{B}$ - the personality disorder group - 99 patients (70.7\%) 


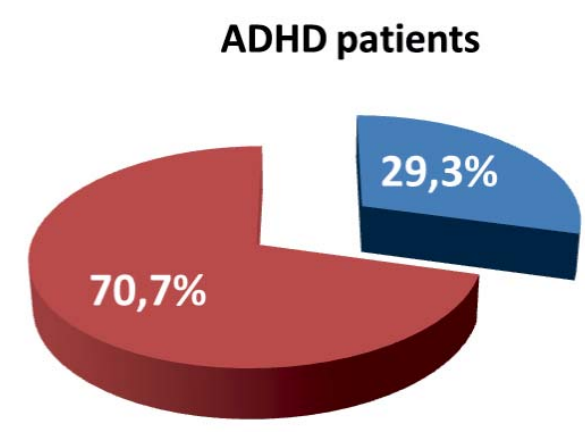

E $\mathrm{A}(\mathrm{ADHD}) \quad \mathrm{B}$ (Personality disorder nonADHD)

Figure 1. ADHD in the sample of personality disorder patients DSM IV.

The ADHD group has three subgroups: the predominantly inattentive type, the hyperactive/impulsive type and the combined type. We found that $17 \%$ are predominantly the inattentive type, $46 \%$ predominantly hyperactive/impulsive type and $37 \%$ the combined type.

The data shows us the increased proportion of the symptoms in the hyperactive/impulsive domain. This is concordant with the classic characteristics of the psychopath: impulsivity, reduced tolerance, emotional disregulation, irritability, restlessness are some of the symptoms that are frequently identified in the individuals with a personality disorder.

The comorbidities were assessed using the MINI. The most representative disorders were depression, alcohol dependence and drug dependence. The other disorders present have been anxiety disorders, psychotic disorders, impulse disorders, somatoform disorders.

The prevalence of ADHD and comorbidities have been evaluated in the initial sample and in the groups identified above: A and B (A - the ADHD group, Bthe personality disorder group).

If we refer to depression, the evaluation showed a prevalence of $56 \%$ of depression in the ADHD group

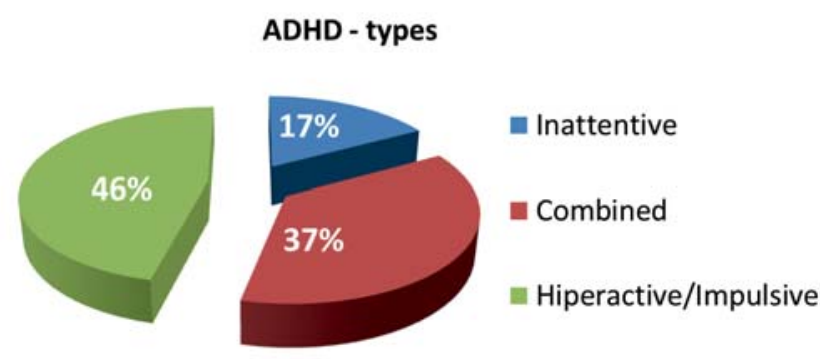

Figure 2. ADHD - types: predominantly inattentive (A), predominantly hyperactive/impulsive (HI) and combined (C) - DSM IV.

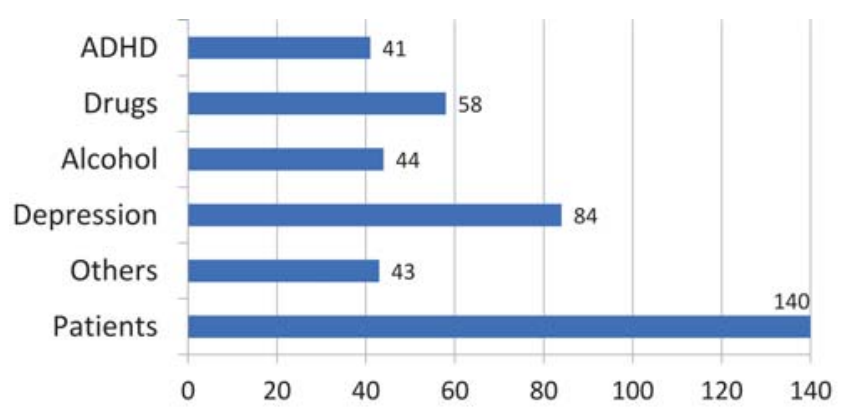

Figure 3. ADHD and other comorbidities in the initial sample of patients with a personality disorder- DSM IV.

and of $62 \%$ in the personality disorder nonADHD group.

Alcohol abuse and dependence has been found to have a prevalence of $24 \%$ in ADHD group and 30\% in the personality disorder nonADHD group.

Other drug abuse and dependence has been found to have a prevalence of $32 \%$ in ADHD group and $44 \%$ in the personality disorder nonADHD group.

Other disorders have been found in a proportion of $39 \%$ in ADHD group and $27 \%$ in the personality disorder nonADHD group.

If we look for the difference between the two groups (the $\mathrm{ADHD}$ and the nonADHD group) in terms of the variables represented by the comorbidities depression, alcohol, drugs and other pathologies, we find the statistical results presented in the table below.

When evaluating the difference between the ADHD group and the nonADHD group in terms of the comorbidities present, it has been found a $p$ value of 0.8201 for depression, that means that the presence of depression does not represent a risk factor for ADHD symptomatology. The same analysis revealed a $p$ value of 0.2483 for alcohol and of 0.4541 for drugs. In the case of other comorbidities $p=0.1702$, that the presence of these comorbidities doesn't discriminate between

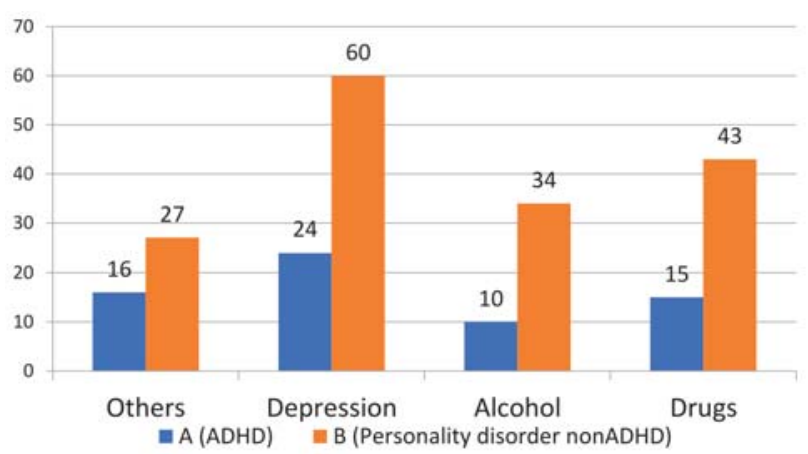

Figure 4. Number of patients with different comorbidities in groups A (ADHD) and B (Personality disorder nonADHD) - DSM IV. 


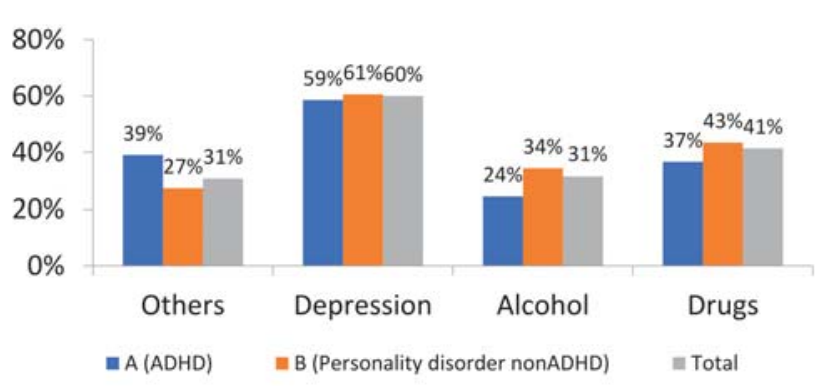

Figure 5. Comorbidities - proportions in groups A (ADHD), B (Personality disorder nonADHD) and initial group.
ADHD patients

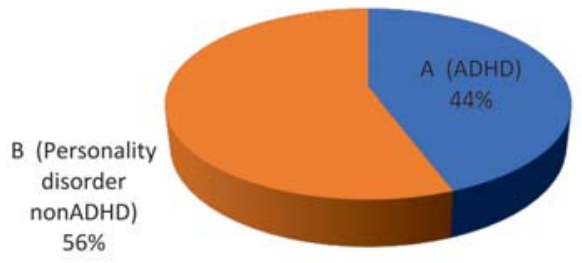

Figure 6. ADHD in the sample of personality disorder patients DSM 5.

Table 1. Prevalence of comorbidities in ADHD and nonADHD group and statistical significance - DSM IV

\begin{tabular}{|l|c|c|c|}
\hline & $\begin{array}{c}\text { ADHD_DSM } \\
\text { IV=Yes (N=41) }\end{array}$ & $\begin{array}{c}\text { ADHD_DSM } \\
\text { IV=No(N=99) }\end{array}$ & p-value (Test) \\
\hline Drugs & $36.6 \%$ & $43.4 \%$ & 0.454069 (Pearson Chi-Square) \\
\hline Alcohol & $24.4 \%$ & $34.4 \%$ & 0.248317 (Pearson Chi-Square) \\
\hline Depression & $58.5 \%$ & $60.6 \%$ & 0.820068 (Pearson Chi-Square) \\
\hline Other comorbidities & $39.0 \%$ & $27.3 \%$ & 0.170163 (Pearson Chi-Square) \\
\hline
\end{tabular}

the two groups, the ADHD individuals and the personality disorder patients (nonADHD). We can say that the two categories can present these disorders independently from attentional or hyperkinetic symptoms.

\section{B. The DSM 5 perspective}

Using the DSM 5 perspective, the initial sample divided into two groups, with a greater proportion of ADHD individuals compared with the DSM IV classification.

A - the ADHD group - 62 patients (44.3\%)

$\mathrm{B}$ - the personality disorder nonADHD group -78 patients $(55.7 \%)$

The proportion of the types has changed. We found that $6 \%$ are predominantly the inattentive type, $42 \%$ predominantly hyperactive/impulsive type and 52\%

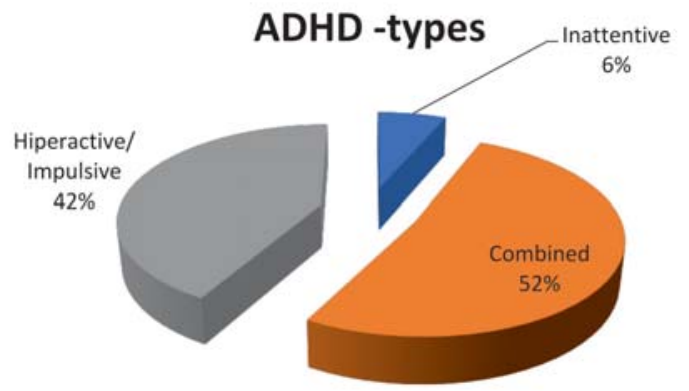

Figure 7. ADHD - types: predominantly inattentive (A), predominantly hyperactive/impulsive (HI) and combined (C) - DSM 5. the combined type. The predominant type is the combined one, followed by the hyperactive/impulsive one.

The prevalence of ADHD and comorbidities have been evaluated in the initial sample and in the groups identified above from the DSM 5 perspective: $A$ and $\mathrm{B}$ (A - the ADHD group, B - the personality disorder group).

The evaluation showed a prevalence of $63 \%$ of depression in the ADHD group and of 58\% in the personality disorder nonADHD group.

Alcohol abuse and dependence has been found in $29 \%$ of cases in ADHD group and 33\% in the personality disorder nonADHD group.

Other drug abuse and dependence has been found in $42 \%$ of cases in ADHD group and $41 \%$ in the personality disorder nonADHD group.

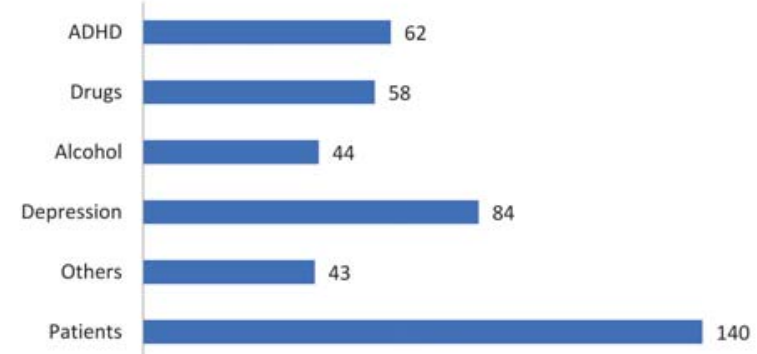

Figure 8. ADHD and other comorbidities in the initial sample of patients with a personality disorder - DSM 5. 


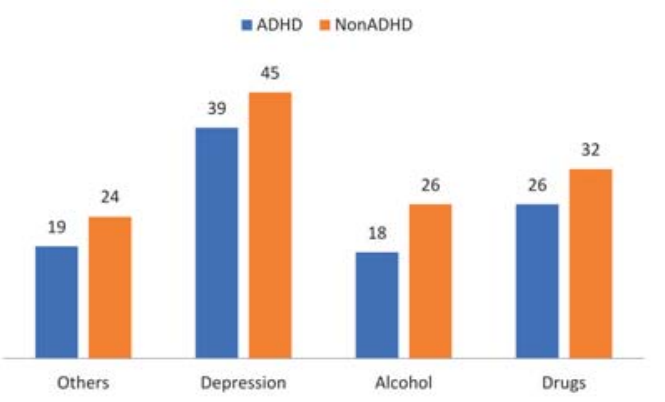

Figure 9. Number of patients with different comorbidities in groups A (ADHD) and B (Personality disorder nonADHD) - DSM 5.

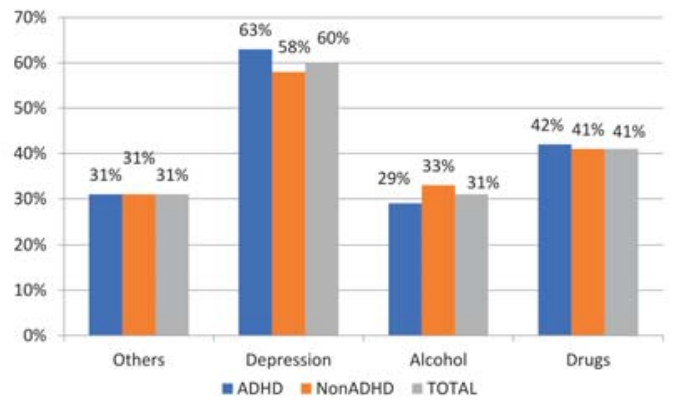

Figure 10. Comorbidities - proportions in groups $A(A D H D)$ and $B$ (Personality disorder nonADHD) - DSM 5.

Table 2. Prevalence of comorbidities in ADHD and nonADHD group and statistical significance - DSM 5

\begin{tabular}{|l|c|c|c|}
\hline \hline & $\begin{array}{c}\text { ADHD_DSM } \\
\text { V=Yes (N=62) }\end{array}$ & $\begin{array}{c}\text { ADHD_DSM } \\
\text { V=No (N=78) }\end{array}$ & p-value (Test) \\
\hline Drugs & $47.9 \%$ & $47.0 \%$ & 0.913555 (Pearson Chi-Square) \\
\hline Alcohol & $29.0 \%$ & $33.3 \%$ & 0.586076 (Pearson Chi-Square) \\
\hline Depression & $62.9 \%$ & $57.7 \%$ & 0.531869 (Pearson Chi-Square) \\
\hline Other comorbidities & $30.6 \%$ & $30.8 \%$ & 0.987388 (Pearson Chi-Square) \\
\hline
\end{tabular}

Other disorders have been found in a proportion of $31 \%$ in ADHD group and in the same proportion in the personality disorder nonADHD group.

Looking for the difference between the two groups (the ADHD and the nonADHD group) in terms of the variables represented by depression, alcohol, drugs and other pathologies, we find the statistical results presented in the table below.

It has been found a $p$ value of 0.5318 for depression. The same analysis revealed a $p$ value of 0.5861 for alcohol and of 0.9136 for drugs. In the case of other comorbidities $\mathrm{p}=0.9874$, that means that the presence of depression, alcohol, drugs or other comorbidities do not represent risk factors for ADHD symptomatology.

\section{Comparison DSM IV - DSM 5}

With the intention of making an analysis of the differences between the two classifications, DSM IV and DSM 5 regarding the ADHD pathology and the relation with the possible comorbidities, the initial sample can be divided into three groups:

Group I - ADHD positive patients after the DSM IV classification, but also after DSM 5

Group II - ADHD positive patients after DSM 5, ADHD negative after DSM IV

Group III- ADHD negative after both DSM IV and 5 .

Groups I, II and III can be interpreted as different levels of severity of ADHD symptomatology (group I

Table 3. Comorbidities - comparison DSM IV - DSM 5. Statistical significance

\begin{tabular}{|l|c|c|c|c|}
\hline & Group I & Group II & Group III & p-value (Test) \\
\hline & $\begin{array}{c}\text { ADHD_DSM } \\
\text { IV or 5 (N=41) }\end{array}$ & $\begin{array}{c}\text { ADHD_DSM } \\
\mathbf{5} \text { (N=21) }\end{array}$ & $\begin{array}{c}\text { ADHD_no } \\
\mathbf{( N = 7 8 )}\end{array}$ & 0.463956 (Pearson Chi-Square) \\
\hline Alcohol & $10 / 41(24.4 \%)$ & $8 / 21(38.1 \%)$ & $26 / 78(33.3 \%)$ & 0.489894 (Pearson Chi-Square) \\
\hline Drugs & $15 / 41(36.6 \%)$ & $11 / 21(52.4 \%)$ & $32 / 78(41.0 \%)$ & 0.496233 (Pearson Chi-Square) \\
\hline Depression & $24 / 41(58.5 \%)$ & $15 / 21(71.4 \%)$ & $45 / 78(57.7 \%)$ & 0.114072 (Pearson Chi-Square) \\
\hline Other comorbidities & $16 / 41(39.0 \%)$ & $3 / 21(14.3 \%)$ & $24 / 78(30.8 \%)$ & \\
\hline
\end{tabular}


Adult ADHD, comorbidities and impact on functionality in a population of individuals with personality disorders

Table 4. Hospitalizations of ADHD patients

\begin{tabular}{|l|c|c|c|}
\hline & ADHD_DSM & ADHD_DSM & p-value (Test) \\
IV=Yes (N=41) & IV=No (N=99) & 0.176233 (Pearson Chi-Square) \\
\hline Hospitalizations & $11 / 41(26.8 \%)$ & $15 / 99(15.2 \%)$ & \\
1 & $12 / 41(29.3 \%)$ & $39 / 99(39.4 \%)$ & $9 / 99(9.1 \%)$ \\
2 & $1 / 41(2.4 \%)$ & $36 / 99(36.4 \%)$ & p-value (Test) \\
3 & $17 / 41(41.5 \%)$ & ADHD_DSM & 0.086976 (Pearson Chi-Square) \\
\hline & ADHD_DSM & V=No (N=78) & \\
\hline Hospitalizations & V=Yes (N=62) & $14 / 78(17.9 \%)$ & \\
1 & $12 / 62(19.4 \%)$ & $30 / 78(38.5 \%)$ & \\
2 & $21 / 62(33.9 \%)$ & $9 / 78(11.5 \%)$ & \\
3 & $1 / 62(1.6 \%)$ & $25 / 78(32.1 \%)$ & \\
\hline
\end{tabular}

\begin{tabular}{|l|c|c|c|c|}
\hline & Group I & Group II & Group III & \\
\hline & ADHD & ADHD & ADHD negative & \\
& DSM IV and 5 positive & $\begin{array}{c}\text { DSM 5 positive, } \\
\text { IV negative }\end{array}$ & & \\
\hline Hospitalizations & $11 / 41(26.8 \%)$ & $1 / 21(4.8 \%)$ & $14 / 78(17.9 \%)$ & \\
0 & $12 / 41(29.3 \%)$ & $9 / 21(42.9 \%)$ & $30 / 78(38.5 \%)$ & \\
1 & $1 / 41(2.4 \%)$ & $0 / 21(0.0 \%)$ & $9 / 78(11.5 \%)$ & \\
2 & $17 / 41(41.5 \%)$ & $11 / 21(52.4 \%)$ & $25 / 78(32.1 \%)$ & \\
3 & &
\end{tabular}

has more ADHD symptoms than group II and group II more than group III).

The results presented in the table above have been statistically interpreted.

The statistical tests used to determine the difference between the prevalence of depression, alcohol use, drug use and other pathologies in the three groups (I, II, III) was the Pearson Chi-Square test.

The $p$ values calculated above showed that the difference is not statistical significant when we refer to depression ( $p=0.4962)$. Likewise, the results in the case of drug and alcohol use show the same absence of statistical significance ( $p=0.4899, p=0.4640)$. In the case of other comorbidities the $p$ value is smaller ( $\mathrm{p}=0.1141$ ), but not enough to detect a statistical significance.

In conclusion, the identification of depression, drug and alcohol pathology and other comorbidities in a population of personality disorder patients does not seem to be associated with the detection of ADHD symptomatology.

Another aspect investigated has been the impact of the overall pathology on the functionality of the patients. From this point of view the necessity of hospital admissions have been studied.

Hospitalizations generally indicate a degree of severity. Following this idea, the presence of hospitalizations has been studied in relation to the ADHD diagno- sis. It has been found that hospital admissions does not seem an important factor in differentiating ADHD population and personality disorder nonADHD population in the DSM IV perspective $(\mathrm{p}=0.1762)$, not even in the DSM 5 perspective ( $\mathrm{p}=0.0870)$, but it seems important in differentiating groups I, II, III ( $\mathrm{p}=0.0326)$ Groups I,II and III can be interpreted as different levels of severity of ADHD symptomatology.

The statistical analysis revealed a difference when comparing the three groups (I, II, III) identified when analyzing the DSM IV and 5 classification. A possible explanation could link the presence of hospital admissions (as showing an overall severity) and the severity of ADHD symptomatology.

Another approach regarding functionality has been investigated using the WFIRS Scale. The total scores and the risk score of $t /$ he ADHD and nonADHD population. The results are relevant in the case of the DSM IV classification ( $\mathrm{p}=0.0029, \mathrm{p}=0.0317$ ) but also in the case of the DSM 5 classification ( $p=0.0052$, $\mathrm{p}=0.0016$ ). Moreover the statistical tests showed a relevance between the two classifications DSM IV and DSM 5, evaluating the difference among groups I,II,III: $p=0.0077, p=0.0069$. The results are shown below.

That means that the functionality evaluation with the WFIRS is able to differentiate the ADHD from 
Laura Aelenei et al.

Table 5. Functional assessement with WFIRS in ADHD patients

\begin{tabular}{|l|c|c|c|}
\hline & $\begin{array}{c}\text { ADHD_DSM } \\
\text { IV=Yes (N=41) }\end{array}$ & $\begin{array}{c}\text { ADHD_DSM } \\
\text { IV=No (N=99) }\end{array}$ & p-value (Test) \\
\hline WFIRS_total & $80.15 \pm 28.6256$ & $64.05 \pm 28.5815$ & 0.002912 (Independent Samples T Test) \\
\hline WFIRS_risc & $15.61 \pm 9.0273$ & $11.95 \pm 9.1041$ & 0.031711 (Independent Samples T Test) \\
\hline & $\begin{array}{c}\text { ADHD_DSM } \\
\text { V=yes (N=62) }\end{array}$ & $\begin{array}{c}\text { ADHD_DSM } \\
\text { V=No (N=78) }\end{array}$ & p-value (Test) \\
\hline WFIRS_total & $76.48 \pm 28.9769$ & $62.63 \pm 28.4888$ & 0.005243 (Independent Samples T Test) \\
\hline WFIRS_risc & $15.74 \pm 9.1238$ & $10.85 \pm 8.7307$ & 0.001587 (Independent Samples T Test) \\
\hline
\end{tabular}

\begin{tabular}{|l|c|c|c|c|}
\hline & Group I & Group II & Group III & P value (test) \\
& $\begin{array}{c}\text { ADHD } \\
\text { DSM IV and 5 positive }\end{array}$ & $\begin{array}{c}\text { ADHD } \\
\text { DSM 5 positive, IV } \\
\text { negative }\end{array}$ & ADHD negative & $\begin{array}{c}0.007691 \text { (ANOVA) } \\
\text { Fara-4 si 5:p_value= } 0.005555\end{array}$ \\
\hline WFIRS_total & $80.15 \pm 28.6256$ & $69.33 \pm 28.9988$ & $62.63 \pm 28.4888$ & $\begin{array}{c}0.006859(\text { ANOVA) } \\
\text { Fara-4 si 5:p_value= } 0.019981\end{array}$ \\
\hline WFIRS_risc & $15.61 \pm 9.0273$ & $16.00 \pm 9.5289$ & $10.86 \pm 8.7307$ & \\
\hline
\end{tabular}

the nonADHD patients, both in the DSM IV perspective and in the DSM 5 perspective. Moreover, the WFIRS score can be linked to the ADHD severity. The WFIRS scores (both total and risk score) differentiate groups I, II, III, that means that they are linked to the severity of the ADHD symptomatology.

Moreover, to support the idea of the relevance of the WFIRS in detecting ADHD symptomatology, we tried to detect correlations between the intensity of ADHD symptomatology and WFIRS scores.

The Pearson Corellation has been calculated for the DIVA total score and the WFIRS total score, $\mathrm{R}=0.278$. That means that there is a weak uphill (positive) linear relationship between the DIVA total score and the WFIRS total score. So, when the individuals score high in the attention or hyperactive/impulsive domain, the impact on functionality evaluated with the WFIRS also increases, but the correlation is defined as rather weak.

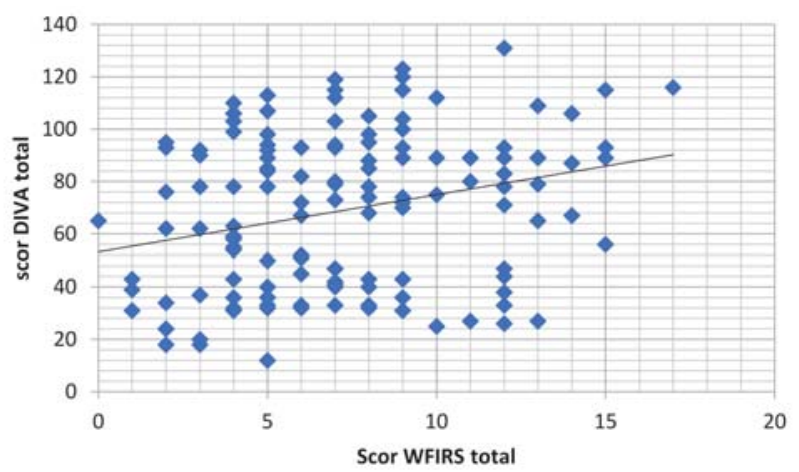

Figure 11. Correlation between DIVA score and WFIRS total score.
The same evaluation is made between the DIVA total score and the WFIRS risk score. Pearson Correlation is $\mathrm{R}=0,212$. That means that there is a weak uphill (positive) linear relationship between the DIVA total score and the WFIRS risk score.

So, individuals show increasing dysfunctionality as evaluated with the WFIRS (in all the domains but also specific in the risk domain) with increasing number of symptoms in the attention or hyperactive/impulsive domain.

\section{CONCLUSIONS}

ADHD is a diagnosis that is found in a considerable proportion in a population of individuals with a personality disorder $-29 \%$ when considering the DSM IV classification and 44\% when referring to the DSM 5 criteria.

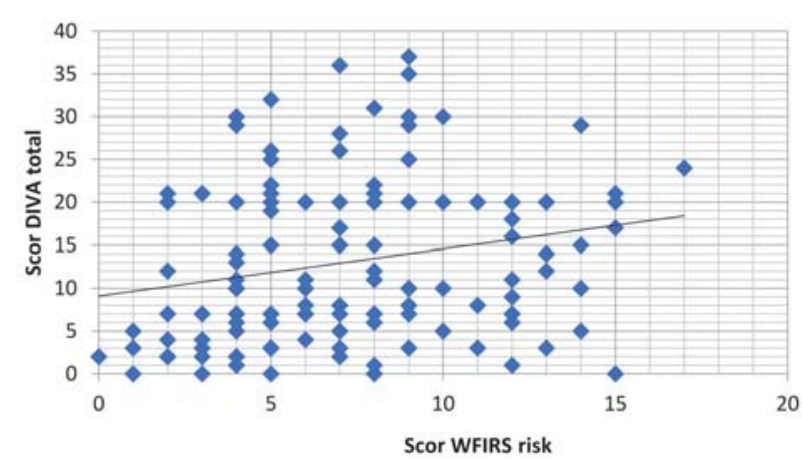

Figure 12. Correlation between DIVA score and WFIRS risk score. 
Depression, drug and alcohol dependence are the most frequent comorbidities identified within the ADHD group, but also in the personality disorder nonADHD group.

From these, the most frequent diagnosis in the ADHD group but also in the personality disorder nonADHD group is depression, followed by substance pathology other than alcohol and then alcohol. More than half of the individuals in both groups had depression. The difference in the prevalence of these comorbidities in the ADHD and nonADHD group is not statistically significant when referring to the DSM IV but also DSM 5 classification.

When comparing the two perspectives, the DSM IV and the DSM 5 classification, in terms of the association between the ADHD symptomatology, the comorbidities and the impact on functionality, the following results were found: comorbidities cannot be considered risk factors for ADHD symptomatology in the population of personality disorder patients; on the other hand, the overall severity and the impact on functionality as assessed with the presence of hospitalizations and the WFIRS scale show a significant importance in differentiating the ADHD symptomatology.

\section{References}

1. American Psychiatric Association. Diagnostic and Statistical Manual of mental Disorders. 5 ed. Washington, DC: American Psychiatric Publishing, 2013

2. American Psychiatric Association. Diagnostic and Statistical Manual of Mental Disorders. 4 ed. Washington, DC: American Psychiatric Publishing, 2000

3. World Health Organization. The ICD-10 classification of mental and behavioural disorders: Clinical descriptions and diagnostic guidelines. Geneva: World Health Organization,1992.

4. Oliva F, Bramante S, Portigliatti A et al. Personality traits and disorders among adult ADHD Patients: Is borderline personality disorder as common as we expect? European Psychiatry. 2017, april, vol 41 suppl

5. Moukhtarian TR, Mintah RS, Moran P, Asherson P. Emotion dysregulation in attention-deficit/hyperactivity disorder and borderline personality disorder. BMC. 2018.

6. Miller C, Flory J., Miller S. Childhood ADHD and the Emergence of Personality Disorders in Adolescence: A Prospective Followup Study. J Clin Psychiatry. 2008 September ; 69(9): 14771484.

7. Torgersen T, Gjervan B. ADHD in adults: A study of clinical characteristics, impairment and comorbidity. Nord J Psychiatry 2006.

8. Rosler M, Retz W. Prevalence of attention deficit/hyperactivity disorder (ADHD) and comorbid disorders in young male prison inmates. Eur Arch Psychiatry Clin Neurosci. 2004 Dec; 254(6):365-71.
The results of this study show that a psychiatric evaluation of personality disorder patients should also point towards a diagnosis like ADHD, in the DSM IV perspective, but especially in the DSM 5 perspective, where the prevalence is higher. Sometimes comorbidities like depression, alcohol and drug abuse and dependence can complicate the clinical picture and affect the prognosis.

\section{Compliance with ethics requirements:}

The authors declare no conflict of interest regarding this article. The authors declare that all the procedures and experiments of this study respect the ethical standards in the Helsinki Declaration of 1975 , as revised in 2008(5), as well as the national law. Informed consent was obtained from all the patients included in the study.

\section{Abreviations: \\ GAF Global Assessement of Functioning \\ CGI Clinical Global Impression}

WFIRS Weiss Functional Impairment Rating Scale

DIVA Diagnostic Interview for ADHD in adults

MINI Mini-International Neuropsychiatric Interview

9. Pliszka SR. Comorbidity of attention-deficit/hyperactivity disorder with psychiatric disorder: an overview. The Journal of Clinical Psychiatry. 1998; 01 Jan, 59 Suppl 7:50-58.

10. Kessler R, Adler L, Barkley R, The Prevalence and Correlates of Adult ADHD in the United States: Results From the National Comorbidity Survey Replication. Am J Psychiatry 2006; 163:716723.

11. Adler L, Cohen J. Diagnosis and evaluation of adults with ADHD. Psychiatr Clin North Am. 2004; 27(2):187-201.

12. Zulauf C, Sprich S, Safren S. The complicated relationship between Attention Deficit Hyperactivity Disorder and Substance Use Disorders. Curr Psychiatry Rep. 2014 March; 16(3)":436 doi:10.1007/s11920-013-0436-6.

13. Brown TE. Emerging understanding of attention deficit disorders and comorbidities. In: Brown TE, ed. Attention Deficit Disorders and Comorbidities in Children, Adolescents and Adults. Washington DC: American Psychiatric Press. 2014, 3-55.

14. Weiss M, Functional Impairment in ADHD. In: Adler LA, Spencer TJ, Wilens TE. Attention-Deficit Hyperactivity Disorder in Adults and Children, Cambridge University Press, 2015, 42-52.

15. Levin FR, Evans S, Kleber HD. Prevalence of adult ADHD among cocaine abusers seeking treatment. Drug Alcohol Depend 1998; 52:15-25.

16. Kessler RC, Adler L, Barkley R et al. The prevalence and correlates of adult ADHD in the United States: Results from the National Comorbidity Survey Replication. Am J Psychiatry 2006; 163(4):716-23. 
17. Willens T. Alcohol and other drug use and attention deficit / hyperactivity disorder. Alcohol Health Res World 1998; 22

18. Chassin L, Rogosch F, Barrera M. Substance use and symptomatology among adolescent children of alcoholics. J Abnorm Psychol 1991; 100(4):449-63.

19. Milin R, Halikas JA, Meller JE, Morse C. Psychopathology among substance abusing juvenile offenders. J Am Acad Child Adolesc Psychiatry 1991; 30(4):569-74.
20. Geffen J, Forster K. Treatment of adult ADHD: a clinical perspective. Ther Adv Psychopharmacol. 2017;8(1):25-32.

21. Kooij JJS, Boonstra AM, Willemsen-Swinkels SHN. Reliability, validity, and utility of instruments or self-report and informant report regarding symptoms of ADHD in adult patients. J Atten Disorders. 2008; 11 (4):445-458 